\title{
Mud-puddling on roadsides: a potential ecological trap for butterflies
}

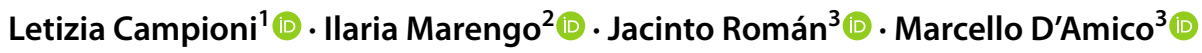

Received: 12 July 2021 / Accepted: 8 December 2021

(c) The Author(s), under exclusive licence to Springer Nature Switzerland AG 2021

\begin{abstract}
Road-kill represents a major threat for butterflies and more generally for pollinators. Here we report an observation of conspicuous aggregations of butterflies mud-puddling on roadsides and, for this reason, being massively road-killed by farm vehicles.

Implications for insect conservation While the reported observation by itself may not entail a significant threat to the populations of the observed species, it provides the opportunity to discuss an overlooked ecological trap, potentially affecting butterflies and especially threatened or endemic species. Indeed, this kind of mortality, due to a very common behaviour in butterflies, could affect any species in any area, and for this reason should be furtherly investigated and, when necessary, appropriately mitigated. Mitigation actions should prevent the formation of moist surfaces along roadsides, and in case of wide verges, provide artificial mud-puddling sites away from roads, in correspondence with the ecotone between roadside and matrix habitat.
\end{abstract}

Keywords Cantabrian Mountains $\cdot$ Lepidopterans Lepidoptera $\cdot$ Foraging $\cdot$ Road ecology $\cdot$ Road-kill

The global spreading of road networks and associated motor traffic represents a major threat to biodiversity and ecosystems worldwide (Laurance et al. 2014; Ibisch et al. 2016). Road-kill is one of the most evident road impacts on animal species, with most research focusing on large vertebrates (D'Amico et al. 2018; Barrientos et al. 2021). Nevertheless, in recent years, studies on the mechanisms determining this impact on insects are increasing (Samways 2020), especially those regarding pollinators (Baxter-Gilbert et al. 2015) and flagship species such as butterflies (Rao and Girish 2007). Overall, road mortality has been suggested to be one of the causes of insect global decline (Thomas et al. 2004; Martin et al. 2018).

Letizia Campioni

letiziacampioni@hotmail.com

1 MARE-Marine and Environmental Sciences Center, ISPA-Instituto Universitário, Rua Jardim do Tabaco 34, 1149-041 Lisbon, Portugal

2 InnovPlantProtect, Estrada de Gil Vaz, Apartado 72, 7351-901 Elvas, Portugal

3 Department of Conservation Biology, Doñana Biological Station CSIC, Calle Américo Vespucio 26, 41092 Seville, Spain
On the other hand, roadsides are increasingly described as suitable habitats for insects ( $\mathrm{Li}$ et al. 2020; Samways et al. 2020), including butterflies. For example, in North American grasslands, restored prairie roadsides act as a corridor habitat for several lepidopteran species (Ries et al. 2001). Nevertheless, most potential benefits for insects inhabiting roadsides can be counterbalanced by overlooked road impacts, such as the chemical pollution affecting both host plants (i.e., the milkweed Asclepias syriaca) and caterpillars of the declining monarch butterfly Danaus plexippus in the eastern United States (Mitchell et al. 2020). In these cases, insect populations inhabiting attractive roadsides actually fall into ecological traps, just as in the case we describe here.

In early August 2020, we observed the presence of conspicuous single- and multi-taxa aggregations of butterflies that were attracted to localised moist ground areas (originated from leaking water coming from mountain streams) on the roadsides of two gravel roads (Fig. 1a). Such behaviour is conventionally termed mud-puddling and occurs in many species of Lepidoptera, and it is thought to serve as a means of acquiring essential resources for adults (i.e., minerals and water; Arms et al. 1974; Adler 1982; Adler and Pearson 1982). Our observations took place in two locations respectively in the Babia Biosphere Reserve (designated Site of Community Interest and Area of Special Protection for 
Fig. 1 Top left: areas of observations, and specific locations within the Cantabrian Mountains. Top right: butterfly aggregation on moist gravel on roadsides while performing mud-puddling behaviour. Bottom right and left: zoom in on several individuals of different butterfly species road-killed by farm vehicles

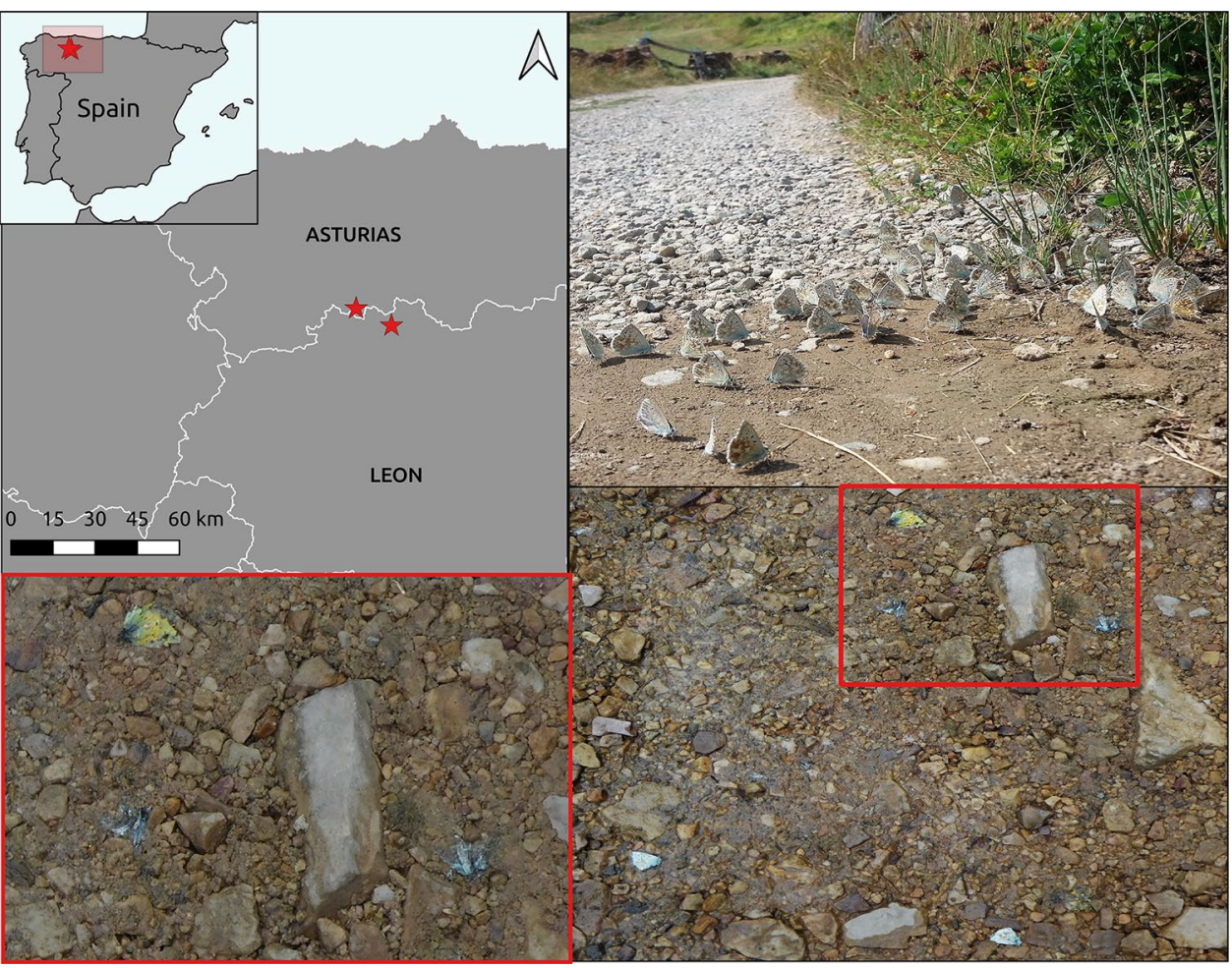

Birds) and the Asturian side of Somiedo Natural Park. The observed butterflies at puddles comprised of five species (nomenclature following Wiemers et al. 2018): the greenveined white Pieris napi, the chalk-hill blue Lysandra coridon, the turquoise blue Polyommatus dorylas, the long-tailed blue Lampides boeticus, and the large skipper Ochlodes sylvanus. Three species (i.e., chalk-hill blue, turquoise blue, and large skipper), have been described as Iberian or even Spanish endemic subspecies (i.e., L. c. asturiensis, P. d. castilla, and $O$. s. faunus), although only L. c. asturiensis is still fully recognized (García-Barros et al. 2013; Table 1). Importantly, the turquoise blue is listed as Near Threatened by the IUCN and also in the European Red List of Butterflies (van Swaay et al. 2010a, 2010b; Table 1). In correspondence with mud-puddling butterflies, we also recorded road-killed individuals (approximately 24\% of the total observed butterflies; Total butterfly observed $\mathrm{N}=54$ ) of the same species above

Table 1 Butterfly species observed mud-puddling on gravel roads and road-killed in the Babia Biosphere Reserve and in the Asturian side of Somiedo Natural Park, Cantabrian Mountains, in early August mentioned. No road-killed individuals have been observed on the surveyed roads far from mud-puddling sites. Despite both gravel roads being closed off to the general traffic, shepherds and farmers drove quads and trucks to seasonally move the livestock from lowland pastures to mountainous areas and vice versa, thus road-killing mud-puddling butterflies (Fig. 1a).

Road-kill risk primarily depends on the presence (and abundance) of individuals on the road and adjacent areas (D’Amico et al. 2015; Visintin et al. 2016). Butterflies are not an exception, and in fact, the available scientific literature shows that the number of road-killed individuals increases according to an increased abundance of butterflies inhabiting the roadsides (Skórka et al. 2013; Gaudel et al. 2020). As a consequence, all the factors attracting butterflies on the roadsides, especially in the areas immediately adjacent to the road, will increase the road-kill risk for these pollinators,

2020. Subspecies marked with asterisks are not fully recognized by recent overviews

\begin{tabular}{lllll}
\hline Species & Subspecies & Family & Conservation status & Distribution range (species and subspecies) \\
\hline Green-veined white Pieris napi & P. n. meridionalis & Pieridae & LC & Palearctic-Mediterranean Europe \\
Chalk-hill blue Lysandra coridon & L. c. asturiensis & Lycaenidae & LC & Central/Southern Europe-Northern Spain \\
Turquoise blue Polyommatus dorylas & P. d. castilla* & Lycaenidae & NT & Southern/Eastern Europe to Western \\
& & & (A2c IUCN criteria) & Asia-Northern Spain \\
Long-tailed blue Lampides boeticus & NA & Lycaenidae & LC & Southern Eurasia, Africa, Australasia-NA \\
Large skipper Ochlodes sylvanus & O. s. faunus* & Hesperidae & LC & European-Northern Iberian Peninsula \\
\hline
\end{tabular}


potentially becoming an ecological trap. Here we report, to our knowledge for the first time, that the presence of moist soils on roadsides can increase the local abundance of mudpuddling butterflies and, consequently, their road-kill risk. Increased road-kill risk usually produces road-kill hotspots (just as previously described for butterflies; Skórka et al. 2015), which in some cases can affect the persistence of local populations.

Road mortality can have a relevant impact on butterfly populations and even species (Thomas et al. 2004). For example, some studies estimated that $2-4 \%$ of monarch butterflies overwintering in Mexico (1.0 to 3.6 million individuals) would be road-killed in a single migration corridor (i.e., the Central Funnel; Kantola et al. 2019). Considering that up to $95 \%$ of road-killed butterflies usually disappear from roads within $48 \mathrm{~h}$ (Skórka 2016), the estimated impact could be even higher. In our case, we observed road mortality for some common species, but also for at least one Spanish endemism (i.e., P. c. asturiensis) and one species listed as Near Threatened at a global scale: the turquoise blue. We have no evidence that the events we witnessed and, more in general, road-kill mortality due to mud-puddling behaviour can have an impact on the population persistence of the observed species. However, this observation provides the opportunity to describe a kind of mortality that could affect any species (with similar ecological requirements) in any areas, especially critically endangered taxa and endemisms with restricted distribution ranges. Road impacts on butterflies, and more in general on pollinators, represent a serious conservation issue because they do not concern only the road-killed species but also negatively affect the communities and ecosystems hosting them (Reck and van der Ree 2015; Fitch and Vaidya 2021). Finally, an interesting issue regarding this observation is that mud-puddling is more frequent among males (Adler and Pearson 1982), potentially leading to sex-biased mortality.

Road impacts on butterflies should be properly mitigated, at least in the areas where road-kills represent a recognized threat for the persistence of local populations. This action can be especially relevant within the distribution area of endangered and endemic species. The most obvious mitigation action would be avoiding the formation of moist surfaces along roadsides, for example, avoiding water stagnation in the areas immediately adjacent to roads. Artificial mud-puddling sites could be also provided away from roads (Sony and Arun 2015). Nevertheless, in order to implement an effective mitigation measure for butterflies inhabiting roadsides, such artificial mud-puddling sites should be created only in wide verges, in correspondence with the ecotone between roadside and matrix habitat. The available scientific literature suggests that the benefits of attracting pollinators on roadsides usually outweigh the costs (Phillips et al. 2020), but the potential existence of overlooked ecological traps such as the one we describe here should suggest that these actions should be always carefully planned.

Supplementary Information The online version contains supplementary material available at https://doi.org/10.1007/s10841-021-00367-y.

Acknowledgements Thanks are due for the financial support to MARE (UIDB/04292/2020 and UIDP/04292/2020). MD was supported by a JdC-Inc post-doctoral grant (IJC2019-039662-I) from the Spanish Ministry of Science and Innovation (MICINN). Sazrina A. Hossin kindly reviewed the English. Two anonymous reviewers provided useful suggestions to improve the manuscript.

\section{Declarations}

Conflict of interest The authors declare that there is no conflict of interest.

Consent to participate The authors have provided their consent to participate to the work.

Consent for publication The authors have provided their consent for publication.

\section{References}

Adler PH, Pearson DL (1982) Why do male butterflies visit mud puddles? Can J Zool 60:322-325

Barrientos R, Ascensão F, D’Amico M, Grilo C, Pereira HM (2021) The lost road: do transportation networks imperil wildlife population persistence? Perspect Ecol Conserv 19(4):411-416

Baxter-Gilbert JH, Riley JL, Neufeld CJ, Litzgus JD, Lesbarrères D (2015) Road mortality potentially responsible for billions of pollinating insect deaths annually. J Insect Conserv 19(5):1029-1035

D’Amico M, Ascensão F, Fabrizio M, Barrientos R, Gortázar C (2018) Twenty years of road ecology: a Topical Collection looking forward for new perspectives. Eur J Wildl Res 64(3):1-2

D’Amico M, Román J, de los Reyes L, Revilla E (2015) Vertebrate road-kill patterns in Mediterranean habitats: who, when and where. Biol Conserv 191:234-242

Fitch G, Vaidya C (2021) Roads pose a significant barrier to bee movement, mediated by road size, traffic and bee identity. J Appl Ecol 58(6):1177-1186

García-Barros E, Munguira ML, Stefanescu C, Vives-Moreno A (2013) Lepidoptera Papilionoidea. In: Ramos MA et al (eds) Fauna Ibérica, vol 37. Museo Nacional de Ciencias Naturales CSIC, Madrid, p 1213

Gaudel P, Paudel M, Gaudel P, Giri BR, Shrestha BR (2020) Mortality census of the road-killed butterflies in Mahendra highway, Nepal. J Insect Biodivers Syst 6(1):87-99

Ibisch PL, Hoffmann MT, Kreft S, Peer G, Kati V, Biber-Freudenberger L, DellaSala DA, Vale MM, Hobson PR, Selva N (2016) A global map of roadless areas and their conservation status. Science 354(6318): 1423-1427

Kantola T, Tracy JL, Baum KA, Quinn MA, Coulson RN (2019) Spatial risk assessment of eastern monarch butterfly road mortality during autumn migration within the southern corridor. Biol Conserv 231:150-160

Laurance WF, Clements GR, Sloan S, O'connell CS, Mueller ND, Goosem M, Venter O, Edwards DP, Phalan B, Balmford A, van der Ree R, Burgues Arrea I (2014) A global strategy for road building. Nature 513(7517):229-232 
Li P, Kleijn D, Badenhausser I, Zaragoza-Trello C, Gross N, Raemakers I, Scheper J (2020) The relative importance of green infrastructure as refuge habitat for pollinators increases with local land-use intensity. J Appl Ecol 57(8):1494-1503

Martin AE, Graham SL, Henry M, Pervin E, Fahrig L (2018) Flying insect abundance declines with increasing road traffic. Insect Conserv Divers 11(6):608-613

Mitchell TS, Agnew L, Meyer R, Sikkink KL, Oberhauser KS, Borer ET, Snell-Rood EC (2020) Traffic influences nutritional quality of roadside plants for monarch caterpillars. Sci Total Environ 724:138045

Phillips BB, Wallace C, Roberts BR, Whitehouse AT, Gaston KJ, Bullock JM, Dicks LV, Osborne JL (2020) Enhancing road verges to aid pollinator conservation: a review. Biol Conserv 250:108687

Rao RSP, Girish MS (2007) Road kills: assessing insect casualties using flagship taxon. Curr Sci, 830-837

Reck H, van der Ree R (2015) Insects, snails and spiders: the role of invertebrates in Road Ecology. In: van der Ree R, Smith DJ, Grilo C (eds) Handbook of road ecology. Wiley, Chichester, pp 247-257

Ries L, Debinski DM, Wieland ML (2001) Conservation value of roadside prairie restoration to butterfly communities. Conserv Biol 15(2):401-411

Samways MJ (2020) Insect conservation: a global synthesis. CABI, Wallingford

Samways MJ, Barton PS, Birkhofer K, Chichorro F, Deacon C, Fartmann T, Fukushima CS, Gaigher R, Habel JC, Hallmann CA, Hill MJ, Hochkirch A, Kaila L, Kwak ML, Maes D, Mammola S, Noriega JA, Orfinger AB, Pedraza F, Pryke JS, Roque FO, Settele J, Simaika JP, Stork NE, Suhling F, Vorster C, Cardoso P (2020) Solutions for humanity on how to conserve insects. Biol Conserv 242:108427

Skórka P (2016) The detectability and persistence of road-killed butterflies: an experimental study. Biol Conserv 200:36-43

Skórka P, Lenda M, Moroń D, Martyka R, Tryjanowski P, Sutherland WJ (2015) Biodiversity collision blackspots in Poland: separation causality from stochasticity in roadkills of butterflies. Biol Conserv 187:154-163

Skórka P, Lenda M, Moroń D, Kalarus K, Tryjanowski P (2013) Factors affecting road mortality and the suitability of road verges for butterflies. Biol Conserv 159:148-157

Sony RK, Arun PR (2015) A case study of butterfly road kills from Anaikatty Hills, Western Ghats, Tamil Nadu, India. J Threat Taxa 7(14):8154-8158

Thomas JA, Telfer MG, Roy DB, Preston CD, Greenwood JJD, Asher J, Fox R, Clarke RT, Lawton JH (2004) Comparative losses of British butterflies, birds, and plants and the global extinction crisis. Science 303(5665):1879-1881

van Swaay C, Cuttelod A, Collins S, Maes D, López Munguira M, Šašic M, Settele J, Verovnik R, Verstrael T, Warren M, Wiemers M, Wynhoff I (2010a) European red list of butterflies. Publications Office of the European Union, Luxembourg

van Swaay C, Wynhof I, Verovnik R, Wiemers M, López Munguira M, Maes D, Šašić M, Verstrael T, Warren M, Settele J (2010b) Polyommatus dorylas. The IUCN Red List of Threatened Species 2010: e.T174262A7039429

Visintin C, van der Ree R, McCarthy MA (2016) A simple framework for a complex problem? Predicting wildlife-vehicle collisions. Ecol Evol 6(17):6409-6421

Wiemers M, Balletto E, Dincă V, Fric ZF, Lamas G, Lukhtanov V, Munguira ML, van Swaay CAM, Vila R, Vliegenthart A, Wahlberg N, Verovnik R (2018) An updated checklist of the European butterflies (Lepidoptera, Papilionoidea). ZooKeys 811:9-45

Publisher's Note Springer Nature remains neutral with regard to jurisdictional claims in published maps and institutional affiliations. 